\title{
Efektivitas Buah Lerak (Sapindus Rarak De Candole) sebagai Bahan Pembersih Logam Perak, Perunggu, dan Besi
}

\author{
Ira Fatmawati \\ Balai Pelestarian Cagar Budaya Jawa Timur \\ Email: ira_fatmawati_chem@yahoo.com
}

\begin{abstract}
Abstrak: Kearifan tradisional dengan memanfaatkan bahan-bahan yang berasal dari alam perlu dikembangkan dan dilestarikan guna mengurangi dampak negatif dari bahan kimia sintetis. Salah satu bentuk kearifan tradisional itu adalah penggunaan buah lerak sebagai bahan pembersih logam. Adanya kandungan saponin menjadikan buah lerak dapat digunakan sebagai bahan baku sabun yang aman, ekonomis, reversibel, dan ramah lingkungan. Penelitian ini bertujuan untuk mengetahui keefektifan larutan lerak serta metode yang tepat untuk membersihkan logam perak, perunggu, dan besi menggunakan larutan tersebut. Sampel yang digunakan adalah mata uang Ma berbahan perak, mata uang Cina berbahan perunggu, dan sabit berbahan besi. Larutan lerak dibuat dengan mencampur 60 gram buah lerak ke dalam $250 \mathrm{ml}$ air panas. Selanjutnya buah ditumbuk dan didiamkan dalam air tersebut selama 24 jam kemudian disaring. Sampel dibersihkan dengan larutan lerak menggunakan dua metode, yaitu : disikat dan direndam. Metode perendaman dilakukan selama 30 menit, 1 jam, 3 jam, 6 jam, dan 24 jam. Hasil penelitian menunjukkan bahwa larutan lerak efektif sebagai bahan pembersih logam perak dan perunggu dengan metode perendaman selama 24 jam kemudian disikat. Namun untuk logam besi, perendaman dalam larutan lerak selama 24 jam kurang efektif karena belum mampu menghilangkan seluruh korosi yang ada di permukaannya.
\end{abstract}

Kata kunci : lerak, perak, perunggu, dan besi

\begin{abstract}
Traditional wisdom by utilizing ingredients derived from nature need to be developed and preserved in order to reduce the negative impact of synthetic chemicals. One of traditional wisdom is the use of lerak fruit as metal cleaning agents. The presence of saponins make lerak fruit can be used as raw material for soap that is safe, economical, reversible, and eco friendly. This research was conducted to determine the effectiveness lerak solution and the proper method for cleaning metal silver, bronze, and iron using the solution. The sample used was the Ma coin made from silver, the Chinese coin made from bronze, and sickle made from iron. Lerak solution were made by mixing 60 grams of lerak fruit into 250 $\mathrm{ml}$ of hot water. Furthermore, fruit is crushed and allowed to stand in the water for 24 hours and then filtered. Samples were cleaned with a lerak solution using two methods : brushed and soaked. Soaking method carried out for 30 minutes, 1 hour, 3 hours, 6 hours, and 24 hours. The results showed that the lerak solution is effective as a cleansing agent for metallic silver and bronze by the method of soaking for 24 hours then brushed. But for ferrous metals, soaking in the lerak solution for 24 hours less effective because not been able to eliminate all the existing corrosion on the surface.
\end{abstract}

Keywords : lerak, silver, bronze, and iron

\section{PENDAHULUAN}

\section{A. Latar Belakang}

Alam menyimpan sejuta potensi yang dapat dimanfaatkan untuk kelangsungan hidup manusia. Dengan kemajuan ilmu dan teknologi yang berkembang saat ini, tidak menutup kemungkinan potensi alam tersebut dapat dieksploitasi dengan lebih baik, meskipun tidak menampik fakta bahwa tradisi leluhur terkadang masih bersifat tepat guna dan secara ilmiah dapat dipertanggungjawabkan keefektifannya. Artinya, tradisi tersebut masih relevan dengan perkembangan zaman sehingga keberadaannya tetap dipertahankan hingga kini. Menurut Keraf (2002), semua bentuk pengetahuan, keyakinan, pemahaman atau wawasan, serta adat kebiasaan atau etika yang menuntun perilaku manusia dalam kehidupan di dalam komunitas ekologi disebut kearifan tradisional yang harus terus digali dan dikembangkan agar kelestariannya tetap terjaga. Adapun menurut Moendardjito dalam Satyananda (2013), tradisi dapat berkembang menjadi kearifan tradisional apabila mampu bertahan terhadap budaya luar, memiliki kemampuan mengakomodasi unsur-unsur budaya luar, mempunyai kemampuan mengintegrasikan unsur budaya luar ke dalam budaya asli, mempunyai kemampuan mengendalikan, dan mampu memberi arah pada perkembangan budaya.

Salah satu bentuk kearifan tradisional yang cukup dikenal oleh masyarakat adalah penggunaan lerak sebagai sabun tradisional. Namun, beredarnya 
bahan-bahan kimia sintetis yang lebih praktis menjadikan lerak kurang banyak diminati sehingga ketersediaannya pun kini semakin langka. Dari beberapa penelitian yang telah dilakukan oleh mahasiswa dan para peneliti menunjukkan bahwa lerak memiliki berbagai manfaat mulai dari sabun wajah, sabun pencuci batik, pembersih logam, pembersih kamar mandi, pembasmi serangga, hingga pembasmi jamur. Selain memiliki keefektifan yang tinggi sebagai bahan pembersih, lerak juga bersifat aman, ekonomis, reversibel, dan ramah lingkungan. Dengan melihat banyaknya manfaat dan kelebihan sifat yang dimiliki lerak, maka penggunaannya perlu dikembangkan terutama sebagai bahan pembersih logam.

Museum Majapahit yang terletak di Kabupaten Mojokerto tepatnya di daerah Trowulan merupakan museum arkeologi yang menyimpan berbagai artefak tinggalan Kerajaan Majapahit. Koleksi logam yang dimiliki museum tersebut antara lain berbahan perak, perunggu, dan besi yang dalam pembersihannya seringkali menggunakan bahan kimia sintetis. Untuk mengurangi dampak negatif penggunaan bahan kimia sintetis sebagai pembersih logam, maka bahan-bahan alami yang memiliki keefektifan sama perlu dikembangkan yang berarti juga melestarikan kearifan tradisional. Oleh karena itu, dalam penelitian ini dilakukan pengujian pembersihan logam perak, perunggu, dan besi menggunakan larutan lerak dengan dua metode, yaitu : disikat dan direndam. Dengan mengetahui keefektifan larutan lerak sebagai bahan pembersih, maka bahan alami ini dapat diaplikasikan pada benda cagar budaya berbahan logam.

\section{B. Rumusan Masalah}

1. Seberapa efektifkah larutan lerak sebagai bahan pembersih logam?

2. Adakah perbedaan hasil yang dicapai pada sampel yang berbeda dengan perlakuan yang sama?

3. Apakah metode penyikatan dan perendaman mempengaruhi tingkat kebersihan logam?

\section{Tujuan Penelitian}

1. Untuk mengetahui keefektifan larutan lerak sebagai bahan pembersih logam dan memastikan jenis logam apakah yang menunjukkan kenaikan tingkat kebersihannya dengan larutan tersebut.

2. Untuk mengetahui metode pembersihan logam yang paling sesuai dengan menggunakan larutan lerak.

\section{Manfaat Penelitian}

1. Hasil pengujian diharapkan dapat dijadikan sebagai metode alternatif pembersihan logam yang aman, ekonomis, reversibel, dan ramah lingkungan.

2. Mengurangi penggunaan bahan kimia sintetis yang terkadang menimbulkan dampak negatif terhadap cagar budaya.

\section{TINJAUAN PUSTAKA}

\section{A. Logam}

Menurut Achmad (2001), logam adalah unsur yang jumlah elektron di kulit terluar atomnya lebih kecil atau sama dengan nomor periode. Hampir empat per lima dari unsur-unsur adalah logam yang gaya ikatnya disebabkan adanya elektron-elektron yang terdelokalisasi. Derajat kohesi besar sebagai akibat dari elektron-elektron yang terdelokalisasi menyebabkan logam memiliki titik leleh, titik didih, dan kerapatan yang tinggi. Dan terjadinya mobilitas elektron valensi menyebabkan logam mempunyai daya hantar listrik serta panas yang baik.

Selain sifat-sifat tersebut, logam juga memiliki sifat yang tidak dimiliki oleh unsur nonlogam, antara lain berwujud padat, keras, dan kuat pada suhu kamar, kecuali raksa $(\mathrm{Hg})$; permukaannya licin dan mengkilap; mudah ditempa dan diregangkan; dan memiliki energi ionisasi yang kecil sehingga cenderung melepaskan elektron.

Permukaan logam umumnya mengalami oksidasi ketika berada di udara pada temperatur ruang dan membentuk lapisan oksida sangat tipis (lapisan kusam). Korosi "kering" ini sangat terbatas dan hanya merusak sebagian kecil permukaan logam. Namun pada temperatur tinggi, hampir semua logam dan paduan bereaksi dengan lingkungan sekitarnya dengan laju yang cukup tinggi dan membentuk lapisan oksida tebal (kerak) yang tidak bersifat melindungi. Pada korosi "basah" atau korosi berair terjadi serangan elektrokimia karena adanya air dan dapat merusak permukaan logam serta menjadi penyebab 
berbagai permasalahan di semua cabang industri (Pinem, 2005 : 303).

Menurut Vlack (1991) dalam Bayuseno (2009), NACE (National Association of Corrosion Engineer) mendefinisikan korosi sebagai penurunan mutu suatu material (biasanya baja) atau sifat-sifatnya yang diakibatkan oleh reaksi dengan lingkungannya. Dan menurut Cahyandaru (2012), peristiwa korosi paling banyak terjadi pada logam besi karena hasil oksidasi besi menghasilkan besi oksida yang porous dan menyebabkan reaksi korosi lebih lanjut. Hal ini berbeda dengan logam seng, timah, maupun timbal yang walaupun lebih mudah mengalami korosi, hasil oksida korosinya akan menutupi permukaan sehingga korosi lebih lanjut tidak terjadi. Lain pula dengan tembaga, perunggu, dan paduannya yang berbahan dasar tembaga. Korosi yang terjadi menyebabkan terbentuknya dua lapisan oksida.

\section{B. Lerak}

Sapindus rarak De Candole merupakan nama binomial dari lerak yang dikenal di Jawa sebagai klerek, di Sunda sebagai rerek, di Palembang sebagai lamuran, di Kerinci sebagai kalikea, dan di Minang sebagai kanikia. Lerak termasuk dalam divisi Spermatophyta yang tumbuh di daerah Jawa dan Sumatera dengan ketinggian 450 - $1500 \mathrm{~m}$ di atas permukaan air laut. Tinggi tanaman dapat mencapai 15 - $42 \mathrm{~m}$ dan batang kayu yang berwarna putih

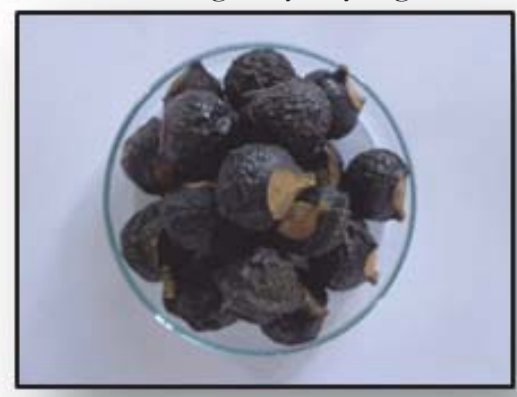

Foto 1: Bagian luar buah lerak

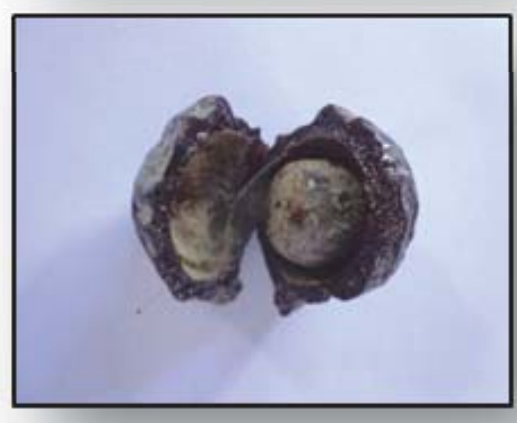

Foto 2: Bagian dalam buah lerak kusam berbentuk bulat dan keras itu dapat berukuran 1 m. Biji tanaman berbentuk bulat, keras, dan berwarna hitam. Buahnya berbentuk bulat, keras, diameter $\pm 1,5 \mathrm{~cm}$, dan berwarna kuning kecoklatan. Di dalam buah terdapat daging buah yang aromanya wangi. Tanaman lerak mulai berbuah pada umur 5 15 tahun. Pada umumnya musim berbuah pada awal musim hujan dan menghasilkan biji sebanyak 1.000 -1.500 biji.

Berdasarkan hasil penelitian yang dimuat di beberapa jurnal menyebutkan bahwa buah, kulit batang, biji, dan daun tanaman lerak mengandung saponin, alkaloid, steroid, antikuinon, flavonoid, polifenol, dan tanin. Menurut Widowati (2003) dalam Syahroni (2013), saponin terdapat pada semua bagian tanaman Sapindus dengan kandungan tertinggi terdapat pada bagian buah. Saponin berasal dari bahasa latin Sapo yang berarti sabun karena sifatnya yang menyerupai sabun. Saponin merupakan senyawa kimia yang berasal dari metabolit sekunder yang banyak diperoleh dari tumbuh-tumbuhan. Struktur kimia saponin yang terdiri dari senyawa polar dan non-polar menjadikan buah lerak dikenal sebagai soapberry atau soapnut. Saponin memiliki sifat berasa pahit, berbentuk busa stabil dalam air, bersifat racun bagi hewan berdarah dingin (seperti : ikan, siput, dan serangga), dapat menstabilkan emulsi, dan menyebabkan hemolisis (rusaknya sel darah merah).

Menurut Sukmasari (2006), saponin temasuk glikosida yang apabila dihidrolisis akan menghasilkan

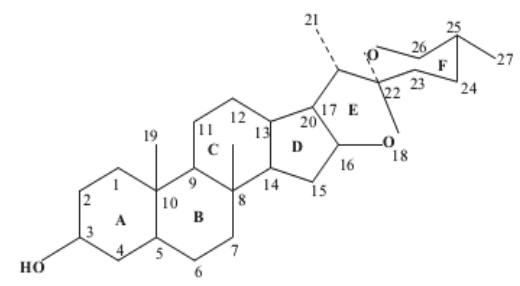

Steroid Neutral Class

Gambar 1 Struktur Steroid

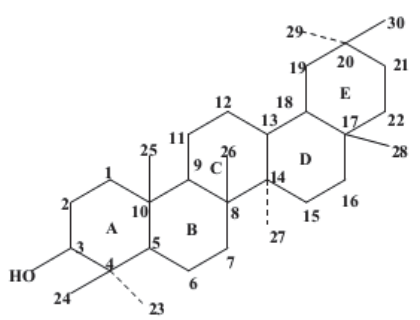

Triterpenoid Class 
sakarida (bersifat hidrofilik) dan sapogenin (bersifat lipofilik). Sapogenin terdiri dari dua golongan, yaitu: saponin steroid dan saponin triterpenoid. Adanya kandungan saponin yang bersifat hidrofilik dan lipofilik tersebut menjadikan buah lerak bersifat surfaktan sehingga dapat digunakan sebagai bahan baku sabun. Di Jawa, khasiat buah lerak ternyata telah lama dikenal oleh masyarakat sebagai sabun pencuci batik. Menurut Heyne (1987) dalam Fitrawati (2007) menyebutkan bahwa buah lerak juga dapat digunakan untuk mencuci logam, sebagai obat jerawat, obat eksim, obat kudis, serta pembunuh serangga.

\section{Metode Penelitian}

Penelitian ini menggunakan sampel dari tiga jenis logam yang unsur penyusunnya berbeda, antara lain : mata uang $\mathrm{Ma}$ berbahan perak, mata uang Cina berbahan perunggu, dan sabit berbahan besi. Bahan, alat, serta prosedur penelitian dapat dijelaskan sebagai berikut :

Bahan :
1. Buah lerak
2. Air

Alat :

1. Timbangan digital

2. Gelas kimia

3. Cawan petri

4. Lumpang dan alu porselin

5. $p H$ indicator paper

6. Pembakar spiritus

7. Spatula

8. Scalpel

9. Sikat

10. Alat penyaring

Prosedur pembuatan larutan lerak:

1. Menyiapkan bahan dan alat yang diperlukan.

2. Menimbang buah lerak hingga mencapai massa \pm 60 gram atau setara dengan \pm 15 biji buah lerak.

3. Memasukkan buah lerak ke dalam gelas kimia yang berisi $250 \mathrm{ml}$ air panas.

4. Didiamkan beberapa saat sampai buah menjadi lunak kemudian tumbuk daging buahnya menggunakan lumpang dan alu porselin.

5. Membiarkan buah lerak di dalam air tersebut selama \pm 24 jam kemudian saring.
6. Larutan lerak siap digunakan.

Prosedur penelitian :

Dalam penelitian ini, sampel dibersihkan dengan larutan lerak menggunakan dua metode, yaitu : disikat dan direndam. Prosedur penelitian untuk ketiga logam tersebut dapat dijelaskan sebagai berikut :

Metode pertama :

1. Sampel logam perak dapat langsung disikat dengan larutan lerak, sedangkan untuk logam perunggu dan besi yang di permukaannya tidak hanya berupa korosi melainkan juga tanah yang telah mengering, maka sebaiknya dilakukan pembersihan terlebih dahulu menggunakan sikat dan scalpel.

2. Kemudian sampel dibilas air mengalir dan dikeringkan.

Metode kedua :

1. Sampel logam perunggu dan besi yang telah dibersihkan menggunakan scalpel selanjutnya direndam dalam larutan lerak sedangkan logam perak langsung direndam dalam larutan lerak. Perendaman dilakukan dengan variasi waktu : 30 menit, 1 jam, 3 jam, 6 jam, dan 24 jam.

2. Selanjutnya, sampel disikat dengan larutan lerak dan dibilas air mengalir kemudian dikeringkan.

\section{HASIL DAN ANALISIS}

Pembuatan larutan lerak menggunakan air panas untuk merendam buah lerak. Hal ini bertujuan agar daging buah menjadi lunak sehingga mudah dihancurkan karena umumnya buah lerak yang dijumpai di pasar dalam keadaan kering. Buah lerak yang daging buahnya berwarna coklat kehitaman tersebut apabila ditumbuk akan mengeluarkan busa yang berwarna putih kecoklatan dan beraroma wangi.

Selanjutnya, buah lerak yang telah hancur tersebut dimasukkan lagi dalam air sehingga warna air berubah dari kuning kecoklatan menjadi coklat kehitaman dan berbusa. Setelah direndam selama \pm 24 jam, buah dapat dipisahkan dari larutannya. Apabila diuji dengan $p H$ indicator paper, larutan lerak tersebut menunjukkan angka yang berkisar antara 4 - 6, artinya larutan bersifat asam. Larutan lerak yang berwarna coklat kehitaman dan beraroma wangi 


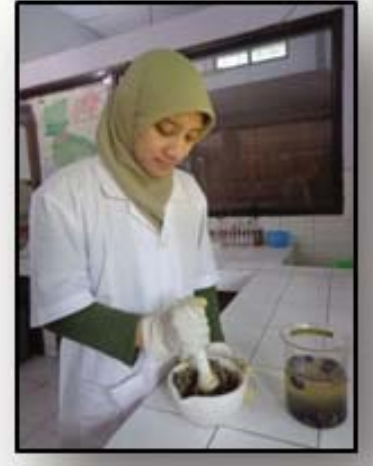

Foto 3 Pembuatan larutan lerak

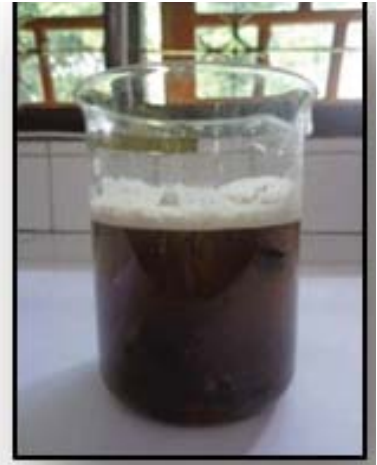

Foto 4 Larutan lerak yang siap digunakan inilah yang digunakan untuk membersihkan logam.

Dalam penelitian ini, larutan lerak yang dibuat langsung diaplikasikan pada logam dan setelah dua hari dari proses pembuatannya larutan tersebut tidak lagi digunakan karena apabila lebih dari tiga hari, larutan akan mengeluarkan bau yang kurang sedap. Oleh karena itu, pembuatan larutan lerak dilakukan sehari sebelum pembersihan logam.

Pembersihan logam perak, perunggu, dan besi menggunakan larutan lerak diperoleh hasil sebagai berikut :

\section{A. Logam Perak}

Dalam penelitian ini dilakukan dua metode pembersihan, yaitu penyikatan dan perendaman yang dilanjutkan dengan penyikatan. Berdasarkan hasil pembersihan logam perak menggunakan larutan lerak dengan metode penyikatan menunjukkan bahwa sebagian besar noda kehitaman pada logam masih melekat dan warna tetap kusam. Ini menandakan bahwa metode penyikatan saja kurang efektif dalam pembersihan logam perak. Pada metode kedua, yaitu metode perendaman yang dilanjutkan dengan penyikatan dilakukan variasi waktu perendaman selama 30 menit, 1 jam, 3 jam, 6 jam, dan 24 jam.

Dari hasil pengamatan dapat diketahui bahwa pada perendaman selama 30 menit, logam mulai terlihat bersih sehingga tampak perbedaan yang signifikan antara logam yang hanya disikat dibanding logam yang direndam kemudian disikat. Logam yang direndam selama 1 jam terlihat lebih bersih dan mengkilap. Tingkat kebersihan dan kecemerlangan logam semakin meningkat seiring dengan lamanya waktu perendaman dan mencapai hasil optimal setelah dilakukan perendaman selama 24 jam.

Pembersihan logam perak menggunakan larutan lerak dengan metode perendaman, tingkat kebersihan yang ditandai dengan berkurangnya noda kehitaman pada permukaan logam serta meningkatnya kecemerlangan logam dapat dicapai ketika waktu perendaman semakin lama. Pembersihan akan memberikan hasil yang maksimal setelah logam yang direndam tersebut disikat. Dengan demikian dapat disimpulkan bahwa logam perak dapat dibersihkan dengan larutan lerak menggunakan metode perendaman selama 24 jam dan dilanjutkan penyikatan. Hasil perlakuan kedua metode pada logam perak dapat ditunjukkan pada Tabel 1.

\section{B. Logam Perunggu}

Seperti halnya logam perak, pembersihan logam perunggu juga menggunakan dua metode. Namun sebelum dilakukan perlakuan, kotoran yang menempel pada permukaan logam perunggu terlebih dahulu dibersihkan menggunakan scalpel. Berdasarkan hasil

\section{Tabel 1 Hasil perlakuan larutan lerak pada logam perak}

$\begin{array}{llll}\text { No. Metode Penelitian } & \text { Sebelum Perlakuan } \\ 1 & \text { Disikat } & \text { Setelah Perlakuan } \\ 2 & \text { Direndam } 30 \text { menit } & \text { Direndam } 1 \text { jam } \\ 3 & \text { Direndam } 3 \text { jam } & \text { Direndam } 6 \text { jam } & \text { Direndam } 24 \text { jam }\end{array}$


Tabel 2 : Hasil perlakuan larutan lerak pada logam perunggu

\begin{tabular}{|c|c|c|c|}
\hline No. & Metode Penelitian & Sebelum Perlakuan & Setelah Perlakuan \\
\hline 1 & Disikat & & \\
\hline 2 & Direndam 30 menit & & \\
\hline 3 & Direndam 1 jam & & \\
\hline 4 & Direndam 3 jam & & \\
\hline 5 & Direndam 6 jam & & \\
\hline 6 & Direndam 24 jam & & \\
\hline
\end{tabular}

pembersihan logam perunggu menggunakan larutan lerak diketahui bahwa logam yang hanya dibersihkan dengan penyikatan, hasilnya kurang maksimal, ditandai dengan masih melekatnya kotoran pada permukaan logam. Ini menunjukkan bahwa metode penyikatan saja tidak mampu membersihkan logam.

Pada metode perendaman yang dilanjutkan penyikatan, tingkat kebersihan logam mulai terlihat setelah logam direndam selama 30 menit dan hampir tidak ada perbedaan yang signifikan pada logam yang direndam selama 1 jam, 3 jam, dan 6 jam. Namun, ketika logam direndam dalam larutan lerak selama 24 jam, sebagian besar kotoran yang menempel dapat terangkat sehingga logam terlihat lebih bersih. Hasil pembersihan pada logam perunggu ternyata berbeda dengan logam perak yang tingkat kebersihannya terlihat jelas di tiap perlakuannya.

Selain lamanya waktu perendaman, keberhasilan dalam pembersihan logam perunggu menggunakan larutan lerak juga dipengaruhi oleh penyikatan, yang mana tingkat kebersihan logam dicapai secara maksimal setelah logam yang direndam tersebut disikat. Selain itu, teknik pembersihan menggunakan scalpel sebelum dilakukan perlakuan dengan larutan lerak juga turut mendukung tercapainya kebersihan pada logam perunggu.

Dengan demikian dapat disimpulkan bahwa logam perunggu dapat dibersihkan dengan larutan lerak menggunakan metode perendaman selama 24 jam dan dilanjutkan dengan penyikatan. Namun sebelum dilakukan perlakuan, kotoran pada permukaan logam perlu dibersihkan agar hasil yang dicapai lebih optimal. Hasil perlakuan logam perunggu dengan larutan lerak tersaji pada Tabel 2.

\section{Logam Besi}

Permukaan logam terlebih dahulu dibersihkan menggunakan sikat dan selanjutnya direaksikan dengan larutan lerak. Metode yang digunakan masih sama seperti sebelumnya, yaitu: disikat dan direndam kemudian disikat. Hasil pengujian menunjukkan bahwa logam yang hanya disikat, sebagian besar korosi masih melekat di permukaannya. Jadi, metode ini kurang efektif dalam membersihkan logam besi.

Pada metode perendaman yang dilanjutkan dengan penyikatan dilakukan variasi waktu perendaman, yaitu: 30 menit; 1 jam; 3 jam; 6 jam; dan 24 jam. Logam yang telah direndam selama 30 menit kemudian disikat terlihat sedikit lebih bersih dibanding sebelum perlakuan. Ini terjadi karena kotoran berupa tanah yang menempel di permukaan logam menghilang, tetapi korosi berwarna merah kecoklatan masih melekat. Sedangkan logam yang direndam selama 1 jam ternyata tidak jauh berbeda dengan logam yang direndam selama 30 menit yang mana korosi masih melekat di permukaannya.

Dalam waktu 2 jam, larutan lerak yang berisi logam besi berubah warna menjadi hitam kecoklatan pada bagian atas dan bagian bawah berwarna coklat muda. Setelah direndam selama 3 jam kemudian disikat, kotoran pada logam terlihat menghilang dan korosi berkurang. Warna putih keperakan dari logam besi mulai terlihat meskipun hanya di sebagian kecil 
Tabel 3 Hasil perlakuan larutan lerak pada logam besi

\begin{tabular}{|c|c|c|c|}
\hline No. & Metode Penelitian & Sebelum Perlakuan & Setelah Perlakuan \\
\hline 1 & Disikat & & \\
\hline 2 & Direndam 30 menit & & \\
\hline 3 & Direndam 1 jam & & \\
\hline 4 & Direndam 3 jam & & \\
\hline 5 & Direndam 6 jam & & \\
\hline 6 & Direndam 24 jam & & \\
\hline
\end{tabular}

permukaan logam.

Logam yang direndam selama 6 jam terlihat lebih bersih karena korosi di permukaannya berkurang sehingga tampak perbedaan yang signifikan dengan logam yang direndam selama 3 jam. Dan ketika waktu rendaman ditingkatkan menjadi 24 jam, maka hampir seluruh korosi yang ada di permukaan logam terangkat sehingga warna putih keperakan tampak lebih dominan. Meski logam terlihat lebih bersih dibanding perlakuan sebelumnya, namun perlakuan ini masih belum mampu menghilangkan seluruh korosi yang ada di permukaan logam.

Dengan demikian dapat disimpulkan bahwa larutan lerak kurang efektif sebagai bahan pembersih logam besi dengan metode perendaman selama 24 jam dan dilanjutkan dengan penyikatan. Perbedaan hasil pembersihan logam besi dengan larutan lerak dapat terlihat pada Tabel 3 .

\section{PENUTUP}

Berdasarkan hasil pembersihan logam perak, perunggu, dan besi menggunakan larutan lerak, maka dapat disimpulkan bahwa :

a. Larutan lerak merupakan bahan pembersih yang efektif untuk logam perak yang mana tingkat kebersihan dan kecemerlangan logam semakin meningkat seiring dengan lamanya waktu perendaman. Seperti halnya logam perak, logam perunggu juga dapat dibersihkan dengan larutan lerak dengan waktu perendaman selama 24 jam. Sedangkan penggunaan larutan lerak untuk logam besi kurang efektif apabila dilakukan perendaman selama 24 jam.

b. Metode pembersihan logam menggunakan larutan lerak dengan variasi waktu perendaman menunjukkan hasil yang hampir sama antara logam perak dan perunggu sedangkan logam besi berbeda. Untuk logam perak dan perunggu tingkat kebersihan dan kecemerlangannya mencapai hasil optimal setelah direndam selama 24 jam. Sedangkan untuk logam besi, meskipun warna putih keperakan mulai terlihat setelah direndam selama 3 jam, namun perendaman selama 24 jam belum memberikan hasil yang 
optimal.

c. Metode penyikatan saja tidak efektif dalam membersihkan logam perak, perunggu, dan besi. Untuk mendapatkan hasil yang optimal, maka metode pembersihan yang digunakan adalah perendaman dan dilanjutkan dengan penyikatan.

Demikian hasil pengujian efektivitas larutan lerak sebagai bahan pembersih logam perak, perunggu, dan besi. Penelitian lanjutan perlu dikembangkan untuk

\section{DAFTAR PUSTAKA}

Achmad, Hiskia. 2001. Kimia Unsur dan Radiokimia. Bandung : PT. Citra Aditya Bakti.

Anonim. 2009. Lerak (Sapindus rarak) Tanaman Industri Pengganti Sabun. Jurnal Warta Penelitian dan Pengembangan Tanaman Industri Volume 15 Nomor 22 Agustus 2009. Badan Penelitian dan Pengembangan Pertanian. Pusat Penelitian dan Pengembangan Perkebunan.

Bayuseno, Athanasius P. 2009. Analisa Laju Korosi pada Baja Untuk Material Kapal Dengan dan Tanpa Perlindungan Cat. Jurnal Rotasi Volume 11 Nomor 3 Juli 2009.

Cahyandaru, Nahar. 2012. Konservasi Logam Secara Umum.

Balai Konservasi Peninggalan Borobudur. Disampaikan dalam Bimbingan Teknis Konservasi Benda-benda Logam tanggal 13 - 17 Juli 2012.

Fitrawati, Juni. 2007. Skripsi Efek Antifungal Berbagai Sediaan dari Buah Lerak Terhadap Candida albicans (Penelitian In Vitro). Medan : Fakultas Kedokteran Gigi. Universitas Sumatera Utara.

Hanafi, Moh. Makalah Saponin. http://www.mhanafi123. wordpress.com diakses tanggal 7 April 2014.

Heyne K. 1987. Tumbuhan Berguna Indonesia. Jakarta : Badan Litbang Kehutanan.

Keraf, S. A. 2002. Etika Lingkungan. Jakarta : Buku Kompas.

Pinem, Muhamad Daud. 2005. Korosi dan Rekayasa Permukaan. Jurnal Teknik Simetrika Volume 4 Nomor 1 April 2005 : 301 - 306. mengetahui lamanya waktu perendaman yang paling efektif dalam membersihkan logam besi. Dengan mengetahui keefektifan dari larutan lerak, maka diharapkan bahan alami ini dapat menjadi metode alternatif dalam pembersihan cagar budaya berbahan logam.

Piputri, Debrita Ayu dan Dewi Lutfiati. 2014. Pengaruh Frekuensi Pencucian Dengan Menggunakan Lerak (Sapindus rarak De Candole) pada Ketajaman Warna Batik Dulit Gresik. e-Journal Volume 03 Nomor 01 Tahun 2014 Edisi Yudisium Periode Februari 2014. Universitas Negeri Surabaya.

Sukmasari, May dan Tjitjah Fatimah. 2006. Analisis Kadar Saponin dalam Daun Kumis Kucing Dengan Menggunakan Metode TLC-Scanner. Jurnal Temu Teknis Nasional Tenaga Fungsional Pertanian. Pusat Penelitian dan Pengembangan Peternakan.

Syahroni, Yan Yanuar dan Djoko Prijono. 2013. Aktivitas Insektisida Ekstrak Buah Piper aduncum L. (Piperaceae) dan Sapindus rarak DC. (Sapindaceae) serta Campurannya Terhadap Larva Crocidolomia pavonana (F.) (Lepidoptera : Crambidae). Jurnal Entomologi Indonesia Volume 10 Nomor 1 : 39 - 50 April 2013. Departemen Proteksi Tanaman. Fakultas Pertanian. Institut Pertanian Bogor.

Vlack, Van dan H. Lawrence. 1994. Ilmu dan Teknologi Bahan (Itmu Baja dan Bukan Baja) 5th ed. Erlangga.

Widowati L. 2003. Sapindus rarak DC. In : Lemmens RHMJ. Bunyapraphastsara N (Eds). Plant Resources of South-East Asia Vol 12 (3). Medicinal and Poisonous Plants. pp. 358-359. Bogor : Prosea Foundation. 